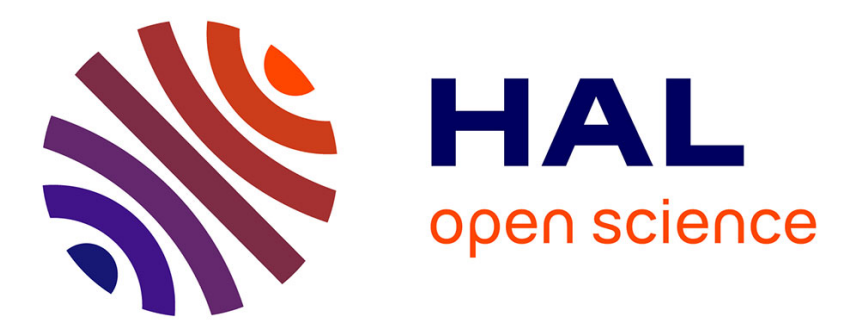

\title{
Peroxidase activity of perennial ryegrass and tall fescue seedlings artificially infected with endophytes
}

Walid Naffaa, Catherine Ravel, Nicole Boyer, Jean-Jacques Guillaumin

\section{To cite this version:}

Walid Naffaa, Catherine Ravel, Nicole Boyer, Jean-Jacques Guillaumin. Peroxidase activity of perennial ryegrass and tall fescue seedlings artificially infected with endophytes. Agronomie, 1999, 19 (7), pp.611-619. hal-00885956

\section{HAL Id: hal-00885956 https://hal.science/hal-00885956}

Submitted on 1 Jan 1999

HAL is a multi-disciplinary open access archive for the deposit and dissemination of scientific research documents, whether they are published or not. The documents may come from teaching and research institutions in France or abroad, or from public or private research centers.
L'archive ouverte pluridisciplinaire $\mathbf{H A L}$, est destinée au dépôt et à la diffusion de documents scientifiques de niveau recherche, publiés ou non, émanant des établissements d'enseignement et de recherche français ou étrangers, des laboratoires publics ou privés. 


\title{
Peroxidase activity of perennial ryegrass and tall fescue seedlings artificially infected with endophytes
}

\author{
Walid Naffaa ${ }^{\mathrm{a}}$, Catherine Ravel ${ }^{\mathrm{b}}$, Nicole Boyer ${ }^{\mathrm{c}}$, Jean-Jacques Guillaumin ${ }^{\mathrm{a}^{*}}$ \\ a Unité de pathologie végétale et mycologie, Inra, 234, avenue du Brézet, 63039 Clermont-Ferrand cédex 02, France \\ b Unité d'amélioration des plantes, Inra, 234, avenue du Brézet, 63039 Clermont-Ferrand cédex 02, France \\ c Laboratoire de Phytomorphogenèse, Université Blaise Pascal, Campus des Cézeaux, 24, avenue des Landais, \\ 63177 Aubière, France
}

(Received 11 May 1999; accepted 15 July 1999)

\begin{abstract}
An increase in peroxidase activity is a common response of plants to various stresses, especially to infection by pathogens. It seemed interesting to study the effects of symbiotic fungi of fodder grasses on the peroxidase activity of their hosts. The peroxidase activity of tall fescue cv. Clarine artificially infected with Neotyphodium coenophialum or with e-endophytes from other hosts ( $N$. lolii and LpTG-2 from Lolium perenne, Epichloë festucae from Festuca gigantea or Koeleria cristata, Epichloë bromicola from Bromus erectus) was generally either lower or not significantly different from that of the non-infected control. Similar results were obtained with perennial ryegrass cv. Vigor artificially infected with different e-endophytes. In contrast, artificial infection of both grasses with Gliocladium-like fungi belonging to the group of p-endophytes provoked an increase in peroxidase activity. These results suggest that p-endophytes can be considered as parasites while e-endophytes, which are not able to trigger a non-specific host defence response, are really mutualistic. (C 1999 Inra/Éditions scientifiques et médicales Elsevier SAS.)
\end{abstract}

clavicipitaceous endophytes / Gliocladium-like / Festuca arundinacea / Lolium perenne / peroxidases

Résumé - Activité peroxydasique de plantules de ray-grass anglais et de fétuque élevée inoculées avec des endophytes. Les plantes stressées (ou attaquées par un pathogène) montrent généralement une augmentation de leur activité peroxydasique. Il a semblé intéressant d'observer l'effet de différents champignons endophytes des graminées sur l'activité peroxydasique de la fétuque élevée (var. Clarine) et du ray-grass anglais (var. Vigor). Clarine, artificiellement inoculée par Neotyphodium coenophialum ou par des e-endophytes isolés d'autres graminées ( $N$. lolii et LpTG-2 de Lolium perenne, Epichloë festucae de Festuca gigantea et de Koeleria cristata, Epichloë bromicola de Bromus erectus) montre généralement une activité peroxydasique inférieure ou comparable à celle du témoin. Des résultats similaires ont été obtenus pour Vigor. En revanche, l'inoculation par un champignon Gliocladium-like, qui appartient au groupe des pendophytes, entraine une augmentation significative de l'activité peroxydasique sur les deux espèces-hôtes. Ces résul-

Communicated by Hervé Thiellement (Geneva, Switzerland)

* Correspondence and reprints

guillaum@clermont.inra.fr 
tats suggèrent le caractère quasi-parasitaire des p-endophytes, tandis que les e-endophytes se comporteraient plutôt comme des symbiotes dont la présence ne déclenche pas l'augmentation de l'activité peroxydasique. (C) 1999 Inra/Éditions scientifiques et médicales Elsevier SAS.)

\section{e-endophytes / Gliocladium-like / Festuca arundinacea / Lolium perenne / peroxydases}

\section{Introduction}

In recent years, the importance of symbiotic interactions between grasses and clavicipitaceous fungal endophytes has been more fully recognised. Knowledge of their taxonomy and relationships with their hosts has considerably progressed. It has been shown that these endophytes, called e-endophytes because they are related to species of Epichloë, form a continuum from antagonism to mutualism according to their mode of transmission [5]. Mutualism concerns symbionts only able to propagate clonally via the seeds of their hosts. These symbionts are classified in the genus Neotyphodium, formerly Acremonium section Albo-lanosa. The main mutualistic effects of clavicipitaceous endophytes are the production of protective anti-herbivore metabolites and their tendency to enhance host growth and stress tolerance $[27,29]$.

In addition, non-clavicipitaceous endophytes from some species of the genera Festuca and Lolium, referred to as p-endophytes $[10]$ or a-endophytes [22], have also been described. P-endophytes include Phialophora-like and Gliocladiumlike Deuteromycetes, which often occur co-symbiotically with e-endophytes on Festuca spp. and Lolium perenne, respectively. Although some results suggest that p-endophytes are commensal with, or antagonistic towards, their hosts $[26,28]$, the ecological importance of $p$ - and aendophyte-grass interactions has not yet been determined.

It has been demonstrated that e- and p-endophytes can be introduced artificially into different host grasses [11]. Such experimental inoculations can help to elucidate compatibility patterns and the range of endophyte hosts. Many successful crossinfections of Epichlö̈ or Neotyphodium endo- phytes have been achieved within or between the genera Festuca and Lolium [3, 9, 13, 21]. However, some of these novel associations showed incompatibility reactions such as the presence of stunted tillers on the new host [3] or the degeneration of endophyte hyphae [9].

Little is known on the physiological processes which could play a role in grass-endophyte relationships. No specific pathogenicity or resistance mechanisms have been reported [12]. However, non-specific reactions from the fungus or the plant have been described; these reactions could explain some cases of incompatibility: i) Clavicipitaceous endophytes can express proteases homologous to other proteases involved in fungal pathogenicity of insects or nematodes $[16,23]$. Such proteases may facilitate colonisation of the host by degrading the plant cell wall and/or the apoplastic proteins providing a nutritional source for the fungus; ii) Endophyte infection can increase the expression of chitinase activity [24]. Chitinase is one of the pathogenesis-related (PR) proteins involved in nonspecific plant defence responses.

The peroxidases constitute a group of enzymes which play the role of oxidoreductases and catalyse the cleavage of the O-O link. In higher plants, the peroxidases are involved in several physiological processes such as the oxidation of indole-3acetic acid (IAA), the oxidation of phenolic compounds and the assembly of the cell wall. Peroxidases that play a major role in the synthesis of lignin [17] are involved in the response of the plant to pathogenic organisms $[18,19,31]$ by strengthening the cell wall. This phenomenon can delay the penetration of pathogens into the plant cells. Therefore, these peroxidases are considered as PR proteins [30].

Since Roberts et al. [24] showed that chitinase synthesis, a non-specific response to fungal infection, can be modified by the presence of an endo- 
phyte, it has been assumed that peroxidase activity could also be influenced by endophytes. The objective of this study was to examine the influence of several endophytes on the peroxidase activity of tall fescue and perennial ryegrass.

\section{Materials and methods}

\subsection{Materials}

The artificial host-endophyte associations used in this study mostly corresponded to those created by Naffaa et al. [21]. They concerned tall fescue (cultivar Clarine from which the natural endophyte was removed) and perennial ryegrass (cultivar Vigor, naturally endophyte-free) inoculated with various endophytes belonging to different groups: e-, p- and a-endophytes (table I).

\subsection{Inoculation}

Endophyte-free seeds were surface sterilised. Seeds were then placed on water agar in Petri dishes and incubated in darkness at $23{ }^{\circ} \mathrm{C} \pm 1$ for 7 days. After germination of the seeds, a longitudinal slit was cut through the tissue of the young seedlings at the junction of the mesocotyl and coleoptile and a drop of solution of ground mycelium in sterile water was placed in the slit.
The mycelium used for inoculation was taken at the periphery of the colonies.

For both cultivars, controls consisted of artificially infected plants where a drop of sterile water was introduced into a wound instead of mycelium.

After inoculation, the seedlings were incubated for 4 days in darkness, then 3 days in light prior to planting in pots. Then, the plants were, after adaptation, grown in the greenhouse.

The plants used for this assay were aged 3 months and had two to six young tillers. The assay was carried out on tillers with three totally developed leaves and in addition, several internal young leaves without flag constituting a pseudo-stem. The fungus was present at least in the sheath of the three oldest leaves.

For most associations, compatibility or incompatibility reactions as well as the level of seed transmission, are reported in table II (from Naffaa [20]).

The second leaf sheath of each studied tiller was used for peroxidase extraction. The first basal $5 \mathrm{~cm}$ of the pseudo-stem of these plants was also used for other extractions.

\subsection{Biochemical methods}

\subsubsection{Extraction of peroxidases}

Leaf sheaths and pseudo-stems $(600 \mathrm{mg}$ fresh weight) were ground at $4{ }^{\circ} \mathrm{C}$ in $0.1 \mathrm{M}$ phosphate buffer

Table I. List of the different novel associations used in this study.

\begin{tabular}{|c|c|c|c|}
\hline Associations & New host species & Endophytes & Natural host species \\
\hline C / Lp-1 & F. arundinacea (cv. Clarine) & LpTG-2 & Lolium perenne \\
\hline C / Lp-80 & F. arundinacea (cv. Clarine) & Gliocladium-like & Lolium perenne \\
\hline $\mathrm{C} / \mathrm{Fa}-3$ & F. arundinacea (cv. Clarine) & N. coenophialum & Festuca arundinaced \\
\hline $\mathrm{C} / \mathrm{Fg}-\mathrm{al}$ & F. arundinacea (cv. Clarine) & Epichloë festucae & Festuca gigantea \\
\hline $\mathrm{C} / \mathrm{Be}-1$ & F. arundinacea (cv. Clarine) & Epichloë bromicola & Bromus erectus \\
\hline $\mathrm{C} / \mathrm{Kc}-1$ & F. arundinacea (cv. Clarine) & Epichloë festucae & Koeleria cristata \\
\hline V/Lp-1 & L. perenne (cv. Vigor) & LpTG-2 & Lolium perenne \\
\hline V / Lp-13 & L. perenne (cv. Vigor) & Neotyphodium lolii & Lolium perenne \\
\hline V / Lp-80 & L. perenne (cv. Vigor) & Gliocladium-like & Lolium perenne \\
\hline V/Lpe-1 & L. perenne (cv. Vigor) & Acremonium sp. & Lolium persicum \\
\hline $\mathrm{V} / \mathrm{Fa}-3$ & L. perenne (cv. Vigor) & N. coenophialum & Festuca arundinaced \\
\hline V/Fg-al & L. perenne (cv. Vigor) & Epichloë festucae & Festuca gigantea \\
\hline $\mathrm{V} / \mathrm{Be}-1$ & L. perenne (cv. Vigor) & Epichloë bromicola & Bromus erectus \\
\hline $\mathrm{V} / \mathrm{Kc}-1$ & L. perenne (cv. Vigor) & Epichloë festucae & Koeleria cristata \\
\hline
\end{tabular}


Table II. Compatibility of the different associations (according to Naffaa [20]).

\begin{tabular}{|c|c|c|c|c|c|}
\hline \multirow[t]{2}{*}{ Associations } & \multicolumn{3}{|c|}{ Host reactions } & \multirow{2}{*}{$\begin{array}{c}\text { Endophyte } \\
\text { Aspect } \\
\text { of hyphae }\end{array}$} & \multirow{2}{*}{$\begin{array}{c}\text { Seed } \\
\text { transmission }(\%)\end{array}$} \\
\hline & Growth & Stunted & $\begin{array}{l}\text { Production of endophyte-free } \\
\text { tillers or plants }\end{array}$ & & \\
\hline $\mathrm{C} / \mathrm{Lp}-1$ & delayed & frequent & frequent & healthy & 93 \\
\hline C / Lp-80 & delayed & rare & frequent & vacuolated & 37 \\
\hline $\mathrm{C} / \mathrm{Fa}-3$ & normal & rare & rare & healthy & 89 \\
\hline $\mathrm{C} / \mathrm{Fg}-\mathrm{al}$ & normal & rare & rare & healthy & 78 \\
\hline $\mathrm{C} / \mathrm{Be}-1$ & normal & rare & rare & healthy & ND \\
\hline $\mathrm{C} / \mathrm{Kc}-1$ & normal & rare & rare & healthy & ND \\
\hline V / Lp-1 & normal & rare & rare & healthy & 100 \\
\hline V/Lp-13 & normal & rare & rare & healthy & 100 \\
\hline $\mathrm{V} / \mathrm{Lp}-80$ & delayed & rare & rare & healthy & 67 \\
\hline V / Lpe-1 & normal & rare & rare & healthy & 0 \\
\hline $\mathrm{V} / \mathrm{Fa}-3$ & delayed & rare & frequent & vacuolated & 25 \\
\hline $\mathrm{V} / \mathrm{Fg}-\mathrm{al}$ & normal & rare & rare & healthy & ND \\
\hline $\mathrm{V} / \mathrm{Be}-1$ & normal & rare & rare & healthy & ND \\
\hline $\mathrm{V} / \mathrm{Kc}-1$ & normal & rare & rare & healthy & ND \\
\hline
\end{tabular}

ND: No Data

$\mathrm{pH} 7$, at a buffer to tissue ratio of $0.5 \mathrm{~mL}$ per $\mathrm{g}$ of fresh weight. The homogenate was centrifuged at $10000 \mathrm{~g}$ for $15 \mathrm{~min}$ at $4{ }^{\circ} \mathrm{C}$. The supernatants were used as enzyme extracts. Each extraction was duplicated.

This procedure allows extraction of soluble enzymes, but not of those enzymes linked to the cell wall.

\subsubsection{Proteins quantification}

The proteins were quantified according to the method of Bradford [2]. Raw extract (5 mL) was added to $1 \mathrm{~mL}$ of Bradford reactant, then the whole was homogenised mildly. The optical density was read after $5 \mathrm{~min}$ of reaction at $595 \mathrm{~nm}$ per min with a spectrophotometre (Philips Unicam).

\subsubsection{Determination of peroxidase activity}

Peroxidase activity was determined according to the method reported by Boyer et al. [1] which is based on the increase in absorption of a substrate after its oxidation by peroxidases. Raw extract $(5 \mathrm{~mL})$ was added to $1000 \mu \mathrm{L}$ of reaction medium containing $900 \mu \mathrm{L}$ of $\mathrm{Na}-$ $\mathrm{K}$ phosphate buffer $(0.15 \mathrm{M}, \mathrm{pH}=6.1)$ with $0.1 \%$ guaiacol and $100 \mu \mathrm{L}$ of $0.5 \% \mathrm{H}_{2} \mathrm{O}_{2}$. Absorbance was read at $470 \mathrm{~nm}$ after $1 \mathrm{~min}$ of reaction. Specific peroxidase activity was expressed as the increase in absorbance at $470 \mathrm{~nm}$ per min and per $\mathrm{mg}$ of proteins [6].

\subsection{Statistical analysis}

Specific peroxidase activity was measured twice (from two distinct extractions) leading to two replicates. As Clarine and Vigor were infected by different sets of endophytes, the data sets from the two hosts were analysed separately.

The influence of each endophyte on specific peroxidasic activity in the leaf sheaths and pseudo-stems of each host was analysed by a variance analysis with one main effect (endophyte isolate). In the case of a significant main effect, means were separated by the twotailed $t$-test of Dunnett which detects whether any treatments are significantly different from the control.

These analyses were performed by means of the procedures GLM of SAS [25].

\section{Results}

Regardless of the host plant, the results showed that specific peroxidase activity was remarkably higher in leaf sheaths than in pseudo-stems (tables $I I I$ and $I V$ ) and the main 'endophyte isolate' effect was highly significant $(P<0.0001)$ for each variable (specific peroxidase activity in leaf sheaths 
Table III. Effects of different endophytes on peroxidase activity expressed as the increase of absorbance at 470 $\mathrm{nm} \cdot \mathrm{min}^{-1} \cdot \mathrm{mg}^{-1}$ of proteins of Festuca arundinacea (cv. Clarine).

a) In the leaf sheath of three-month-old plants

\begin{tabular}{lcccr}
$\begin{array}{l}\text { Endophyte } \\
\text { isolate }\end{array}$ & $\begin{array}{c}\text { Peroxidase } \\
\text { activity }\end{array}$ & $\begin{array}{c}\text { Difference between endophyte } \\
\text { isolate and the control means }\end{array}$ & $\begin{array}{l}\text { Lower } \\
\text { confidence limit at the 0.05 level }\end{array}$ \\
\hline Lp-80 & 589 & $222 * * *$ & 147.1 & 296.9 \\
Lp-1 & 401 & 34 & -40.9 & 108.9 \\
Control & 367 & -20 & -94.9 & 54.9 \\
Be-1 & 347 & -72 & -146.9 & 2.9 \\
Kc-1 & 295 & $-100 * * *$ & -174.8 & -25.1 \\
Fa-3 & 267 & $-141 * * *$ & -215.9 & -66.1 \\
Fg-1a & 226 & & & Upper \\
\hline
\end{tabular}

b) In the pseudo-stem of the three-month-old plants

\begin{tabular}{lcccc}
\hline $\begin{array}{l}\text { Endophyte } \\
\text { isolate }\end{array}$ & $\begin{array}{c}\text { Peroxidase } \\
\text { activity }\end{array}$ & $\begin{array}{c}\text { Difference between endophyte } \\
\text { isolate and the control means }\end{array}$ & $\begin{array}{l}\text { Lower } \\
\text { confidence limit at the 0.05 level }\end{array}$ \\
\hline Lp-80 & 536 & $438^{* * *}$ & 380.5 & 495.5 \\
Be-1 & 159 & $61^{* * *}$ & 3.5 & 118.5 \\
Lp-1 & 122 & 24 & -33.5 & 81.5 \\
Kc-1 & 102 & 4 & -53.5 & 61.5 \\
Control & 98 & 0 & -57.5 & 57.5 \\
Fa-3 & 98 & -46 & -103.5 & 11.5 \\
Fg-1a & 52 & & & Upper \\
\hline
\end{tabular}

*** Significant comparison at the 0.05 level.

and pseudo-stems). The comparison of means gave different results according to the associations considered.

\subsection{Festuca arundinacea}

In the association between Clarine and the Gliocladium-like (Lp-80), specific peroxidase activity in the second leaf sheath was slightly higher than that measured in the pseudo-stem (table $I I I)$. In the other associations, the peroxidase activity in the leaf sheath was considerably higher than that measured in the pseudo-stem.

The Dunnett test shows that in associations with the Gliocladium-like, the peroxidase activity in sheaths and pseudo-stems was significantly higher than that observed in the controls, while these variables were not influenced by LpTG- 2 and one strain of Epichloe festucae (Kc-1). Associations with $N$. coenophialum (Fa-3) and E. festucae from Festuca gigantea (Fg-1a) exhibited a significantly weaker reaction in the leaf sheath than the controls, whereas there was no difference in the pseudostem. E. bromicola significantly increased the peroxidase activity in the pseudo-stem of tall fescue while it did not influence that observed in the leaf sheath.

\subsection{Lolium perenne}

In most associations, peroxidase activity in the leaf sheath was significantly lower than that of the control (table IVa), with the exception of E. festucae (Fg-1a), which did not alter the reaction observed in the leaf, and Gliocladium-like which significantly increased peroxidase activity. Such a 
Table IV. Effects of different endophytes on peroxidase activity expressed as the increase of absorbance at 470 $\mathrm{nm} \cdot \mathrm{min}^{-1} \cdot \mathrm{mg}^{-1}$ of proteins of Lolium perenne (cultivar Vigor).

a) In the leaf sheath of three-month-old plants

\begin{tabular}{lcccc}
\hline $\begin{array}{l}\text { Endophyte } \\
\text { isolate }\end{array}$ & $\begin{array}{c}\text { Peroxidase } \\
\text { activity }\end{array}$ & $\begin{array}{c}\text { Difference between endophyte } \\
\text { isolate and the control means }\end{array}$ & $\begin{array}{c}\text { Lower } \\
\text { confidence limit at the 0.05 level }\end{array}$ \\
\hline Lp-80 & 453 & $198 * * *$ & 129.6 & 266.4 \\
Control & 255 & -57 & -125.4 & 11.4 \\
Fg-1a & 198 & $-108 * * *$ & -176.4 & -39.6 \\
Lp-13 & 147 & $-114 * * *$ & -182.4 & -45.6 \\
Be-1 & 141 & $-133 * * *$ & -201.4 & -64.6 \\
Fa-3 & 122 & $-147 * * *$ & -215.4 & -78.6 \\
Lpe-1 & 108 & $-159 * * *$ & -227.4 & -90.6 \\
Kc-1 & 96 & $-161 * * *$ & -229.4 & -92.6 \\
Lp-1 & 94 & & & Upper \\
\hline
\end{tabular}

b) In the pseudo-stem of the three-month-old plants

\begin{tabular}{lcccc}
\hline $\begin{array}{l}\text { Endophyte } \\
\text { isolate }\end{array}$ & $\begin{array}{c}\text { Peroxidase } \\
\text { activity }\end{array}$ & $\begin{array}{l}\text { Difference between endophyte } \\
\text { isolate and the control means }\end{array}$ & $\begin{array}{l}\text { Lower } \\
\text { confidence limit at the 0.05 level }\end{array}$ \\
\hline Lp-80 & 202 & $149 * * *$ & 120.1 & 177.9 \\
Control & 53 & -1 & -29.9 & 27.9 \\
Lp-13 & 52 & -3 & -31.9 & 25.9 \\
Lpe-1 & 50 & -8 & -36.9 & 20.9 \\
Fg-1a & 45 & -11 & -39.9 & 17.09 \\
Fa-3 & 42 & -12 & -40.9 & 16.9 \\
Be-1 & 41 & -22 & -51.4 & 6.4 \\
Lp-1 & 30 & $-30 * * *$ & -58.9 & -1.1 \\
Kc-1 & 23 & & & Upper \\
\hline
\end{tabular}

*** Significant comparison at the 0.05 level

result was not observed in pseudo-stems; only two associations (with Gliocladium-like and E. festucae from Koeleria cristata) showed a peroxidase activity significantly different from that of the control (table $I V b$ ). In the pseudo-stem, following the general trend, the Gliocladium-like increased the level of peroxidase activity; in contrast, the strain of $E$. festucae (Kc-1) decreased this activity.

\section{Discussion}

The infection of grasses by endophytic fungi is significant from both an ecological and an agronomical point of view, yet very little is known about interactions between the two organisms. A better knowledge of these interactions could be useful for generating novel associations of agricultural interest. Plants exposed to various environmental stresses respond by synthesising a set of proteins, including peroxidases. Moreover, specific lignin-forming peroxidases are considered as PR proteins [30] and classified as PR-6. Therefore, peroxidase activity could be one out of many markers indicating how the host plant responds to endophyte infection.

Our results show that soluble peroxidase activity is influenced by the age of the plant organs and by the presence of the endophyte. 
Peroxidase activity was always higher in the leaf sheath than in the pseudo-stem. Such a result is not surprising because peroxidase activity generally increases with age [1]. As the second leaf sheath was older than the leaves forming the pseudo-stem, the age of each organ accounts for the results obtained.

As regards the endophytes, three different reactions were observed: the peroxydase activity of each association was lower, not significantly different, or higher than that of the control (table III and $I V)$.

An enhanced peroxidase activity was expected because it is a common response of plants to stresses, such as pathogen infection. Moerschbacher et al. [18] observed such a response for resistant near-isogenic wheat lines infected by stem rust. Ye et al. [31] also reported increased peroxidase activity in tobacco infected by the mosaic virus. This activity was linked with biochemical changes in the cell wall and could be due to specific peroxidases (PR-6). Mouzeyar [19] showed that the global peroxidase activity of sunflower was increased by infection by the downy mildew (Plasmopara halstedii). In our study, infection by the Gliocladium-like significantly increased the peroxidase activity of the host. In the association involving this endophyte, peroxidase activity was high even in young organs. This may indicate that the Gliocladium-like triggers a systemic defence mechanism thus confirming that this endophyte is parasitic rather than mutualistic, as postulated by Siegel et al. [28].

According to Naffaa et al. [21], despite the delayed growth of seedlings, the association between perennial ryegrass and Gliocladium-like is stable (table II). Though Gliocladium-like was not in co-symbiosis with an e-endophyte, the host plants looked healthy. Such observations seem inconsistent with the enhanced peroxidase activity. However, the results were quite different in $F$. arundinacea. For tall fescue infected by Gliocladium-like, peroxidase activity in leaf sheaths was almost equal to that observed in pseudo-stems. In addition, the plants with this endophyte showed delayed growth and were able to dis- card their novel endophyte, resulting in a low rate of seed transmission (table $I I$ ). In this case, the enhanced peroxidase activity was associated with morphological responses. This confirms that Gliocladium-like is recognised as pathogenic by tall fescue. As this endophyte is not natural for this species, it cannot overcome the defence responses of tall fescue.

Epichloë bromicola (Be-1) induced a significantly enhanced peroxidase activity in the pseudostem of tall fescue (table $1 I I \mathrm{l}$ ). As this isolate from Bromus erectus can form stromata on its natural host, it is antagonistic rather than mutualistic and it is not surprising that it triggers a defence response from tall fescue. On the contrary, it is more surprising to observe that the peroxidase activity of perennial ryegrass in the leaf sheath can be significantly decreased by this fungus. Leuchtmann and Schardl [14] reported that E. bromicola contains both stroma-forming and non-stromal strains. Our results suggest that the same isolate of E. bromicola might have an antagonist or mutualistic effect, depending on the species into which it is introduced. Unfortunately, plants harbouring $E$. bromicola died as a result of technical problems, and it was not possible to observe whether they formed stromata on the two hosts.

On the other hand, most e-endophytes decreased or did not significantly alter peroxidase activity of their novel hosts. In leaf sheaths of perennial ryegrass, all the e-endophytes used (with the exception of the strain Fg-la of E. festucae), as well as the isolate of a-endophyte, Lpe-1, significantly decreased peroxidase activity (table IIIa). The same behaviour was also observed in tall fescue inoculated with $N$. coenophialum $(\mathrm{Fa}-3)$ and $E$. festucae (Fg-1a) (table IVa). In the pseudo-stem of perennial ryegrass and tall fescue, most associations responded as the control (tables $I I I b$ and $I V b)$. The different reactions of young and adult leaves can be explained by the process of plant colonisation by e-endophytes; endophytes are more abundant in the first leaf sheaths than in the younger tissues, colonised later [8], and their metabolic activity is higher in mature tissues [7]. 
It is also worth noting that different strains of a same species can trigger different reactions, as was the case of Fg-1a and $\mathrm{Kc}-1$, both belonging to $E$. festucae. This can be explained by the considerable genetic differentiation of $E$. festucae which can be harboured by several Festuca species [15]. Moreover, Christensen et al. [4] noted that different isolates of $E$. festucae provoked different morphological reactions (isolates referred as stunting or non-stunting) when they were introduced into novel hosts. Neither of the two isolates of E. festucae used in this study provoked any morphological reaction in their novel host, nor did they enhance its peroxidase activity.

However, there is no direct relationship between peroxidase activity and morphological reactions. Despite the delayed growth of tall fescue seedlings inoculated by Lp-1 (table II), their peroxidase activity was not significantly higher than that of the control. This might indicate that tall fescue accepted this novel endophyte, an hypothesis confirmed by the high rate of seed transmission of the endophyte in its novel host (table II). Conversely, the association between Vigor and $N$. coenophialum did not appear to be compatible (table II) though the peroxidase activity of the host was not altered by the presence of the fungus.

Our results show that e-endophytes, even introduced into novel hosts, do not generally enhance peroxidase activity. Reddy et al. [23] reported that mutualistic fungal endophytes and some Epichlö̈ species express a protease close to proteases suspected to be virulent factors in pathogen systems. Moreover, Roberts et al. [24] showed an increased level of chitinase in endophyte-infected tall fescue. Therefore, in our experiment, the host was expected to exhibit defence reactions. But this was not the case. The lack of enhanced peroxidase activity by e-endophytes may facilitate the colonisation of their host. This phenomenon may indicate that many e-endophytes are not recognised by tall fescue and perennial ryegrass. These fungi may have developed similar mechanisms to escape recognition by grasses. However, the peroxidases are only one group of enzymes involved in the defence reaction of higher plants against micro-organisms. Study of additional systems (PAL, chitinases, glu- canases, etc.) might lead to slightly different conclusions. In addition, the procedure used for extraction yields only a fraction of the peroxisases (soluble peroxidases) leaving in the pellet the enzymes linked to the cell wall.

\section{References}

[1] Boyer N., Gaspar T., Lamond M., Modifications des peroxidases et de l'allongement des entrenoeuds de bryone à la suite d'irritations mécaniques, $\mathrm{Z}$. Pflanzenphysiol. 93 (1979) 459-470.

[2] Bradford M., A rapid and sensitive method for the quantification of microgram quantities of proteins utilizing the principle of protein-dye binding, Anal. Biochem. 72 (1976) 248-254.

[3] Christensen M.J., Variation in the ability of Acremonium endophytes of Lolium perenne, Festuca arundinacea and $F$. pratensis to form compatible associations in the three grasses, Mycol. Res. 99 (1995) $466-470$.

[4] Christensen M.J., Ball O.J.P, Bennett R.J., Schardl C.L., Fungal and host genotype effects on compatibility and vascular colonization by Epichlö̈ festucae, Mycol. Res. 101 (1997) 493-501.

[5] Clay K., Clavicipitaceous fungal endophytes of grasses: coevolution and change from parasitism to mutualism, in: Pirozynski K.A., Hawksworth D. (Eds.), Coevolution of Fungi with Plants and Animals, Academic Press, London, 1988, pp. 79-105.

[6] De Jaegher G., Boyer N., Gaspar T., Thigmomorphogenesis in Bryonia dioica: changes in soluble and wall peroxidases, phenylalanine ammonialyase activity, cellulose, lignin content and monomeric constituents, Plant Growth Regul. 3 (1985) 133-148.

[7] Herd S.M., Christensen M.J., Saunder K., Scott D.B., Schmid J., Quantitative assessment of metabolic activity and gene expression of an endophytic fungus, Microbiology 143 (1997) 267-275.

[8] Hinton D.M., Bacon C.W., The distribution and ultrastructure of the endophyte of toxic tall fescue, Can. J. Bot. 63 (1985) 36-42.

[9] Koga H., Christensen M.J., Bennett R.J., Cellular interactions of some grass/Acremonium endophyte associations, Mycol. Res. 97 (1993) 1237-1244. 
[10] Latch G.C.M., Christensen M.J., Samuels G.J., Five endophytes of Lolium and Festuca in New Zealand, Mycotaxon 20 (1984) 535-550.

[11] Latch G.C.M., Christensen M.J., Artificial infection of grasses with endophytes, Ann. Appl. Biol. 107 (1985) 17-24.

[12] Leuchtmann A., Systematic, distribution, and host specificity of grass endophytes, Nat. Toxins 1 (1992) 150-162.

[13] Leuchmann A., Isozyme characterisation, persistence, and compatibility of fungal and grass mutualists, in: Bacon C.W., White J.F. Jr (Eds), Biotechnology of Endophytic Fungi of Grasses, CRC Press, Boca-Raton, 1994, pp. 47-56.

[14] Leuchtmann A., Schardl C.L., Mating compatibility and phylogenetic relationship among two new species of Epichlö̈ and other congeneric European species, Mycol. Res. 102 (1998) 1169-1182.

[15] Leuchtmann A., Schardl C.L., Siegel M.R., Sexual compatibility and taxonomy of a new species of Epichloë symbiotic with fine fescue grasses, Mycologia 86 (1994) 802-812.

[16] Lindstrom J.T., Belander F.C., Purification and characterization of an endophytic fungal proteinase that is abundantly expressed in the infected host grass, Plant Physiol. 106 (1994) 7-16.

[17] Moerschbacher B.M., Plant peroxidase: Involvement in response to pathogens, in: Penel C., Gaspard T., Greppin H. (Eds.), Plant Peroxidases 1980-1990, University of Geneva, pp. 91-99.

[18] Moerschbacher B.M., Noll U.M., Flott B.E., Reisener H.J., Lignin biosynthetic enzymes in stem rust infected, resistant and susceptible near-isogenic wheat lines, Physiol. Mol. Pl. Pathol. 33 (1988) 33-46.

[19] Mouzeyar S., Étude de la résistance du tournesol, Helianthus annuus L., au mildiou causé par Plasmopara halstedii, Ph.D. thesis, Université Blaise Pascal, Clermont-Ferrand, 1993.

[20] Naffaa W., Les champignons endophytes des graminées: variabilité et co-adaptation avec leurs hôtes, Ph.D. thesis, Université Blaise Pascal, ClermontFerrand, 1998.
[21] Naffaa W., Astier C., Ravel C., Guillaumin J.J., Artificial infection of perennial ryegrass and tall fescue with endophytes from 11 different species of grasses, Agronomie 19 (1999) 133-144.

[22] Naffaa W., Ravel C., Guillaumin J.J., A new group of endophytes in European grasses, Ann. Appl. Biol. 132 (1998) 211-226.

[23] Reddy P.V., Lam C.K., Belanger F.C., Mutualistic fungal endophytes express a proteinase that is homologous to proteases suspected to be important in fungal pathogenicity, Plant Physiol. 111 (1996) $1209-1218$

[24] Roberts C.A., Marek S.M., Niblack T.L., Karr A.L., Parasitic Meloidogyne and mutualistic Acremonium increase chitinase in tall fescue, J. Chem. Ecol. 18 (1992) 1107-1116.

[25] SAS Institute Inc., SAS/STAT User's Guide, Version 6, Fourth Edition, SAS Institute Inc., Cary, 1989.

[26] Schmidt D., Du nouveau sur les endophytes de la fétuque des prés, Rev. Suisse Agric. 26 (1994) 57-63.

[27] Siegel M.R., Latch G.C.M., Johnson M.C., Fungal endophytes of grasses, Annu. Rev. Phytopathol. 25 (1987) 293-315.

[28] Siegel M.R., Schardl C.L., Phillips T.D., Incidence and compatibility of non-clavicipitaceous fungal endophytes in Festuca and Lolium grass species, Mycologia 87 (1995) 196-202.

[29] Van Heeswijck R., Mac Donald G., Acremonium endophytes in perennial ryegrass and other pasture grasses in Australia and New-Zealand, Austr. J. Agric. Res. 43 (1992) 1683-1709.

[30] Van Loon L.C., Pierpoint W.S., Boller T., Conejero, V., Recommendations for naming plant pathogenesis-related proteins, Plant Mol. Biol. Rep. 12 (1994) 245-264.

[31] Ye X.S., Pan S.Q., Kuc J., Association of pathogenesis-related proteins and activities of peroxidase, $\beta$-1,3-glucanase and chitinase with systemic induced resistance to blue mould of tobacco but not to systemic tobacco mosaic virus, Physiol. Mol. Plant Pathol. 36 (1990) 523-531. 